\title{
A dose-escalation clinical trial to evaluate the safety and immunogenicity of a replication- defective HIV-1 vaccine-HIVAX
}

\author{
F Tung $^{1 *}$, J Tung $^{1}$, M Fischl $^{2}$ \\ From AIDS Vaccine 2012 \\ Boston, MA, USA. 9-12 September 2012
}

\section{Background}

Replication-defective SIV elicited protective immunity in animals. In this first-in-human therapeutic vaccination study, a replication-defective HIV-1 vaccine was tested in HIV-1 infected subjects under antiretroviral therapy.

\section{Methods}

A010 is an ongoing randomized, placebo-controlled dose-escalation clinical trial to evaluate the safety and the immunogenicity of two doses of a replication defective HIV-1 vaccine (HIVAX ${ }^{\mathrm{TM}}$ ) in subjects receiving stable highly active antiretroviral therapy (HAART) who have an HIV-1 RNA $<50$ copies/ml and CD4 cell count $>500$ cells $/ \mathrm{mm} 3$. Following the randomized placebo-controlled vaccination phase subjects who received active vaccine and who meet eligibility will undergo a 12-week analytical antiretroviral treatment interruption.

\section{Results}

HIVAX $^{\mathrm{TM}}$ is well tolerated in HIV infected subjects. Only mild injection site reaction occurred with transient duration. No medical treatment is necessary. High level of cellmediated immune responses measured by ELISPOT assay was noticed after vaccination.

\section{Conclusion}

The replication defective HIV vaccine appears no severe adverse effect in HIV-1 infected subjects. High level of cell-mediated immune response was elicited in the vaccinees. HIVAX ${ }^{\mathrm{TM}}$ is worth for further evaluation of protective efficacy.

${ }^{1}$ GeneCure Biotechnologies, Norcross, GA, USA

Full list of author information is available at the end of the article

\author{
Author details \\ ${ }^{1}$ GeneCure Biotechnologies, Norcross, GA, USA. ${ }^{2}$ University of Miami, Miami, \\ $\mathrm{FL}$, USA.
}

Published: 13 September 2012

doi:10.1186/1742-4690-9-S2-P127

Cite this article as: Tung et al:: A dose-escalation clinical trial to

evaluate the safety and immunogenicity of a replication-defective HIV-1 vaccine-HIVAX. Retrovirology 2012 9(Suppl 2):P127.

Submit your next manuscript to BioMed Central and take full advantage of:

- Convenient online submission

- Thorough peer review

- No space constraints or color figure charges

- Immediate publication on acceptance

- Inclusion in PubMed, CAS, Scopus and Google Scholar

- Research which is freely available for redistribution

Submit your manuscript at www.biomedcentral.com/submit

\section{() Biomed Central}

